\title{
СТАНОВЛЕННЯ ТА ФОРМИ ОРГАНІЗАЦІЇ ЕКОЛОГІЧНОГО АУДИТУ НА СІЛЬСЬКОГОСПОДАРСЬКИХ ПІДПРИЕМСТВАХ
}

\section{Рецензент - кандидат економічних наук К. Ю. Вергал}

\begin{tabular}{|c|}
\hline Розглянуто становлення екологічного аудиту в \\
Україні та форми організачії екологічного аудиту \\
на сільськогосподарських підприємствах краӥни. \\
Визначено об'єкти, суб 'єкти та план проведення \\
екологічного аудиту. Проведено аналіз основних \\
факторів та етапів формування екологічного \\
аудиту на сільськогосподарських підприємствах. \\
Запропоновано схему організаиії екологічного \\
аудиту на сільськогосподарських підприємствах. \\
\hline
\end{tabular}

Ключові слова: система аудиту, екологічний аудит, форми організачії екологічного аудиту.

Постановка проблеми. Нині в Україні спостерігається антропогенне й техногенне навантаження на навколишнє природне середовище. Збалансування елементів природного середовища та економічних показників результатів діяльності сільськогосподарських підприємств можливе за умови впровадження на підприємствах ефективної інтегрованої системи екологічного менеджменту та екологічного аудиту $[7$, с. 61] як незалежної форми контролю за функціонуванням системи. Недосконала система управління сільськогосподарськими підприємствами в Україні, невміння застосовувати науково обгрунтований еколого-економічний підхід зменшує можливість країни у майбутньому зайняти гідне місце на світовому продовольчому ринку. Тому в умовах стійкого розвитку країни необхідна нова культура, де охорона навколишнього середовища й раціональне використання природних ресурсів $\epsilon$ найпріоритетнішими.

Аналіз останніх досліджень i публікацій, у яких започатковано розв'язання проблеми. Перед науковцями наразі постають питання формування концептуальних основ екологічного аудиту системного елемента державного управління та контролю. Дослідження проблем формування і розвитку екологічного аудиту здійснюється як економістами, так і науковцями з інших галузей - соціологами, фахівцями державного управління. 3-поміж них варто відзначити наукові розробки таких вчених як О. Л. Михайлюк, У. П. Новак, Т. І. Пізняк, М. М. Огородник, В. В. Рибак, В. Ф. Семенова,

\section{С. Є. Шутка.}

Питаннями обгрунтування особливостей функціонування сільськогосподарських підприємств в умовах системи екологічного менеджменту та місця екологічного аудиту в цій системі вивчало чимало науковців і практиків, зокрема: С. Ю. Булигін, І. Р. Дегодюк, С. С. Сайко, М. В. Ільїна, Т. А. Кирсанова, К. Л. Лучишина, Г. М. Скупар, I. Р. Юргутіс. Однак на сьогодні ще не сповна досліджено питання взаємодії системи екологічного менеджменту із загальною системою управління підприємством та порядку проведення екологічного аудиту в системі контролю за їх діяльністю.

Метою статті є дослідження становлення та сутності екологічного аудиту; аналіз форми організації екологічного аудиту на сільськогосподарських підприємствах України.

Методи дослідження. В основу дослідницької роботи покладений комплекс загальнонаукових та економічних методів і принципів: об'єктивізму, системності, багатоваріантності. Дотримання принципів стало можливим завдяки використанню таких методів економічного дослідження як аналітикосинтетичного, порівняльного, статистичного, розрахунково-конструктивного, моделювання, узагальнення.

Результати дослідження. Формування та становлення ринкових відносин викликало необхідність перегляду ролі існуючих економічних інструментів еколого-економічної політики й виникнення нової економічної парадигми. Одним із запропонованих інструментів їх впровадження є екологічний аудит. Екологічний аудит - документально оформлений системний незалежний процес оцінювання об'єкта екологічного аудиту, що включає збирання й об'єктивне оцінювання доказів для встановлення відповідності визначених видів діяльності, заходів, умов, системи управління навколишнім природним середовищем та інформації з цих питань вимогам існуючого законодавства України про охорону навколишнього природного середовища та іншим критеріям екологічного аудиту [1].

\footnotetext{
* Науковий керівник-доктор економічних наук В. В. Писаренко
} 


\section{СТОРІНКА МОЛОДОГО ВЧЕНОГО}

Передумовами формування екологічного аудиту стало розуміння погіршення стану навколишнього середовища, необхідності охорони та використання природних ресурсів. Вперше екологічний аудит почав використовуватися в 70-ті роки минулого століття в США як засіб захисту інтересів підприємницьких структур, спрямований на регулювання заходів в охороні навколишнього середовища [1]. До середини 80-х років $\mathrm{XX}$ ст. екологічний аудит виступав як метод внутрішнього адміністративного управління для посилення контролю за екологічними аспектами діяльності підприємства.

У 1989 році Міжнародна торговельна палата опублікувала документ, який дав початок внутрішньому аудиту як процедурі самоконтролю та інструменту внутрішнього менеджменту [2]. Внутрішній екологічний аудит підприємства охоплює аналіз внутрішнього контролю управління виробничим процесом, оцінку слабких сторін, урахування ризику для навколишнього середовища, збір доказів практичної ефективності внутрішнього екологічного контролю [1].

У 1993 році Комісія європейських співтовариств виступила з першим проектом обов'язкових правил екологічного аудиту. Водночас із правилами екологічного аудиту Міжнародна організація зі стандартизації завершила розробку міжнародних норм екологічного управління підприємством ISO14000. Було сформульовано основне завдання екоаудиту - збір достовірної вихідної інформації про виробничу діяльність об'єкта та формування на іiі основі висновків щодо реального екологічного стану об'єкта (екологоємкості, екологічної оцінки обладнання й технологій, якості продукції). Екологічний аудит вирішував також низку функціональних завдань: корегування, оперативний контроль та формування стратегії розвитку [1].

Перші кроки впровадження екологічного аудиту в Україні припадають на 90-ті роки XX століття. Передумовою цього було ухвалення Програми технічної допомоги «Розвиток управління навколишнім природним середовищем в Україні (район басейну р. Дніпро)» відповідно до Декларації про співробітництво між урядами України та Канади від 31.03.1994 року.

У 2004 році в Україні було прийнято Закон «Про екологічний аудит», який є основним документом, що визначає основні правові та організаційні принципи здійснення екологічного аудиту й спрямований на підвищення екологічної обгрунтованості та ефективності діяльності суб'єктів господарювання [3]. На основі цього закону розрізняють наступні форми екологічного аудиту: внутрішній та зовнішній; обов'язковий і добровільний екологічний аудит.

Основними об'єктами екологічного аудиту є: сировина; продукти харчування, харчоблоки; технологічні процеси; продукція; викиди в атмосферу; стічні води; відходи; засоби індивідуального і колективного захисту; техніка безпеки; положення про політику Компанії в області охорони праці і навколишнього середовища; екологічний паспорт підприємства й ін. Суб'єктами екологічного аудиту $є$ замовники (органи виконавчої влади, органи місцевого самоврядування, керівники чи власники об'єктів екологічного аудиту) та виконавці (юридичні або фізичні особи). Таким чином, екологічний аудит орієнтований на внутрішні індивідуальні потреби підприємства відповідно до його політики та встановлених цілей. До того ж важливим є ідентифікація мети і задач діяльності підприємства, перш ніж визначити, який тип екологічного аудиту йому необхідний.

Крім того у 2004 році створено Державний центр екологічної сертифікації Державного екологічного інституту Міністерства охорони навколишнього природного середовища України, який здійснює сертифікацію та реєстрацію екологічних аудиторів і спрямований на підвищення екологічної обгрунтованості всіх суб'єктів господарювання. У 2005 році на рівні Міністерства охорони навколишнього природного середовища України було затверджено методичні рекомендації щодо підготовки, здійснення та оформлення звіту про екологічний аудит, які розроблені відповідно до положень Законів України «Про екологічний аудит», «Про внесення змін до деяких законів України з метою забезпечення врахування екологічних вимог у процесі приватизації», «Про охорону навколишнього природного середовища», інших нормативно-правових актів України, державних стандартів України ДСТУ ISO 19011-2003, ДСТУ ISO 14000-1997, з урахуванням рекомендацій Світового банку та положень Протоколу екологічного аудиту Свропейського банку реконструкції та розвитку [3].

У 2008 році відбулося перше засідання Спілки екологічних аудиторів України, в ході якого екоаудитори, які мають відповідні сертифікати, ухвалили рішення про створення Всеукраїнської громадської організації. Спілка екологічних аудиторів України покликана на добровільних засадах об'єднувати сертифікованих екологічних аудиторів, трудові колективи екоаудиторських фірм, а також інших фахівців і організацій, дія- 
льність яких пов'язана або сприяє розвитку екологічного аудиту в Україні. Основною метою Спілки є захист соціальних, економічних і професійних інтересів екологічних аудиторів, розвитку, екологоаудиторської діяльності в Україні згідно з вимогами Закону України «Про екологічний аудит», розвитку національної системи екологічного менеджменту і сертифікації відповідно до існуючої міжнародної і вітчизняної практики [4].

Екологічний аудит $€$ інструментом системи екологічного менеджменту, перевагами впровадження якої є: посилення екологізації виробничо-господарської діяльності підприємств, зменшення витрат на виробництво, зменшення витрат на утилізацію відходів, поліпшення іміджу підприємств, розширення ринків збуту для екологічно чистих товарів [1].

Основними факторами екоаудиту є [1]:

- аудиторська оцінка екологічних витрат;

- аудиторські оцінки екологічних ризиків;

- формування висновку підприємств 3 експлуатації при реструктуризації галузі;

- аудиторська оцінка програмних заходів ресурсозбереження;

- аудиторська оцінка нормативної бази;

- аудиторська оцінка умов екологічного страхування.

Завдяки екоаудиту досягаються такі результати [1]:

- підвищення ефективності використання сировинних та енергетичних ресурсів, а також зменшення негативного впливу виробництва на навколишнє середовище;

- обгрунтування необхідності та можливість концентрації зусиль і коштів на найбільш пріоритетних напрямах екологічної діяльності;

- зменшення економічних ризиків та запобігання розвитку надзвичайних ситуацій.

Екоаудит може вплинути на формування та розвиток ринку екологічних послуг в Україні, в тому числі в сфері екологічного менеджменту, екологічної сертифікації та страхування. Складність сучасних екологічних проблем викликає необхідність застосування аудиторського підходу до їх досліджень. По-перше, за таких умов забезпечується високий рівень проведення стягнень у процесі оцінки екологічних проблем. По-друге, в аудиторському підході пріоритет надається критеріям незалежності та об'єктивності у проведенні досліджень та формуванні висновків [1].

Екологічний аудит включає перевірку таких видів діяльності [1]:

1. Виконання екологічних нормативів відповідно до законодавства.

2. Функціонування системи екоуправління.

3. Отримання екологічного сертифіката.

4. Складання екологічної декларації та звітів компанії про екологізацію діяльності.

Загальний план проведення екологічного аудиту включає три стадії - попередню стадію, стадію аудиту та заключну стадію (див. табл.).

План екологічного аудиту

\begin{tabular}{|c|c|}
\hline Стадії & Дії \\
\hline \multirow{4}{*}{ Попередня } & Планування сфери аудиту \\
& Підбір кадрів для проведення \\
& аудиту \\
& Аналіз особливостей галузі \\
& Залучення персоналу \\
\hline & Перевірка звітності підприємства \\
Аудит & Дослідження політики \\
& підприємства \\
& Аналіз напрямів менеджменту \\
& Вибіркове опитування персоналу \\
& Технічне інспектування \\
\hline \multirow{3}{*}{ Заключна } & Оцінка результатів \\
& Підготовка звіту \\
& Розробка плану дій \\
\hline
\end{tabular}

Екологічний аудит на сучасному етапі реформування економіки України має бути обов'язковою складовою системи менеджменту підприємства. Введення в дію системи стандартів екологічного аудиту повинно стати першим важливим кроком до становлення дієвої системи менеджменту спеціалізованого підприємства на засадах сталого розвитку, а саме проведення екологічного аудиту як незалежної перевірки екологічності господарської діяльності діючого підприємства, охорони навколишнього середовища з метою ії достовірності, повноти, реальності, відповідності природоохоронному законодавству, регламентуючим актам і для напрацювання рекомендацій зі зниження фактичних або потенційних екологічних, фінансових та інших збитків, екологічних затрат [5]. На основі системи дослідження запропоновано наступну схему екологічного аудиту сільськогосподарських підприємств (див. рис.). 
СТОРІНКА МОЛОДОГО ВЧЕНОГО

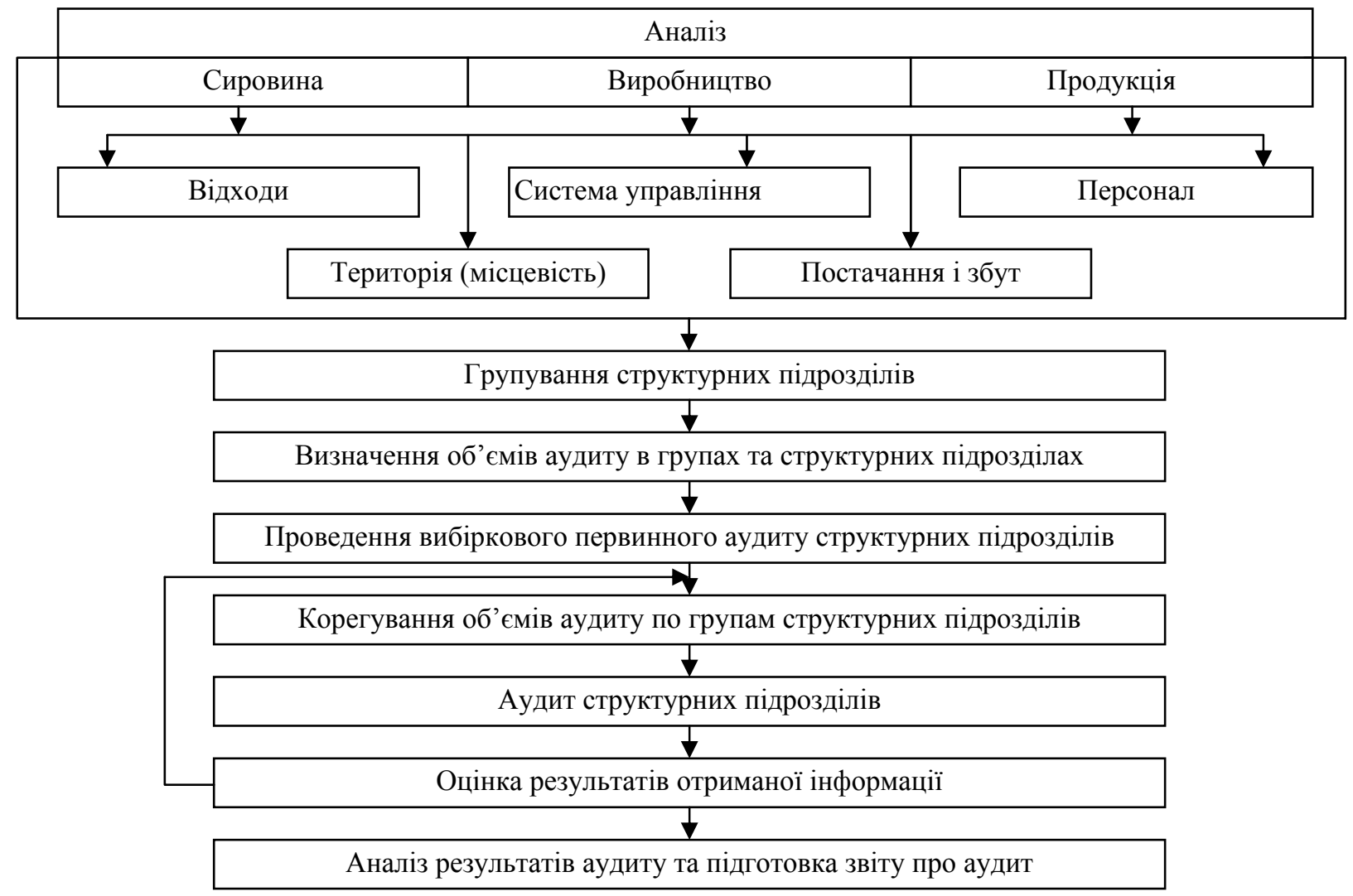

Рис. Схема організації екологічного аудиту на сільськогосподарських підприємствах (доопрацьовано автором на основі [6])

Перспектива розвитку екологічного аудиту на державному рівні повинна бути спрямована на подальшу стабілізацію виробництва та збільшення обсягів випуску екологічно чистої продукції, підвищення конкурентоспроможності на внутрішньому і зовнішньому ринках за рахунок поліпшення екологічних характеристик продукції, розширення ринків збуту, підвищення продуктивності праці та економічної ефективності виробництва, ефективне використання сировинних і паливно-енергетичних ресурсів [1].

Екологічний аудит повинен посісти рівноправні позиції поряд із екологічною експертизою та екологічною інспекцією, поскільки він дає можливість без додаткових бюджетних витрат посилити управління охороною навколишнього середовища й підвищити ефективність екоменеджменту. Тому держава повинна бути зацікавленою в розвитку екологічного аудиту та створенні відповідних правових і нормативних основ його функціонування.

Висновки. Таким чином, доведено, що:

1) на сьогодні принципи та процедури екологічного аудиту діють на основі міжнародних стандартів ISO 14000, що являють собою екологічні рекомендації всієї господарської діяльнос- ті. Саме застосування цих стандартів дає змогу сільськогосподарським підприємствам України забезпечувати власну конкурентоспроможність на внутрішньому та зовнішньому ринках;

2) екологічний аудит повинен посісти рівноправні позиції поряд із екологічною експертизою та екологічною інспекцією, поскільки він дає можливість без додаткових бюджетних витрат посилити управління охороною навколишнього середовища, підвищити ефективність екоменеджменту. Тому держава має бути зацікавленою в розвитку екологічного аудиту та створенні відповідних правових і нормативних основ його функціонування;

3) проведення екологічного аудиту забезпечить: підвищення ефективності використання сировинних ресурсів і зменшення негативних впливів від використання неекологічних технологій; концентрацію зусиль і ресурсів на пріоритетних напрямах господарської діяльності; зменшення екологічних ризиків та попередження розвитку негативних екологічних явищ; зменшення ризиків виникнення конфліктних ситуацій на підприємствах; формування ефективної системи контролю за екологічним розвитком сільськогосподарських підприємств. 


\section{БІБЛІОГРАФІЯ}

1. Огородник М. М., Новак У. П. Тенденції розвитку екологічного аудиту як інструменту системи екологічного менеджменту [Електронний ресурс] - Режим доступу: // http//www.nbuv.gov.ua/portal/natural/VNULP/Men egment/2009 647/76.pdf.

2. Пригара I. $О$. Теоретичні основи екологічного аудиту [Електронний ресурс] - Режим доступу : http://www.nbuv.gov.ua/portal/soc_gum/Nvbdfa/20 11_2/prygara.pdf.

3. Семенова В.Ф. Екологічний менеджмент: Навч. посіб. / В. Ф. Семенова, О. Л. Михайлюк. К. : Знання, 2006. - 366 с. - (Вища освіта XXI століття). - ISBN 966-346-188-8.

4. Учредительное собрание Союза экологических аудиторов Украины [Електронний ресурс]: [Украинский центр экологического аудита и страхования.
Рубрика : ООО УкрЭкоАудит] - Режим доступу: http://www.ukrecoaudit.com/news.php?newsid $=576$.

5. Фостолович B. A. Екологічний аудит в системі екологічного менеджменту сільськогосподарських підприємств / В. А. Фостолович, О. О. Яковенчук, Я. О. Яковенчук // Всеукраїнський науково-виробничий журнал «Інноваційна економіка». - 2011. - № 4. - С. 61-65. [Електронний ресурс]. - Режим доступу : http://www.nbuv.gov.ua/ portal/Soc_Gum/inek/2011_4/61.pdf.

6. Шутка С. $С$. Особливості впровадження екологічного аудиту в період реформування економіки України / С. Є. Шутка // Науковий вісник НЛТУ України: збірник науково-технічних праць. - 2008. - Вип. 18.9. - С. 308-315.

7. Экологический учет и аудит : Сб. статей. - М. : ФБК - ПРЕСС, 1997. - 192 с. 